\title{
INTELLIGENT HOME AUTOMATION
}

\author{
Sooraj.S.Babu ${ }^{1}$, Arafath.P ${ }^{2}$, Kannan.K.K ${ }^{3}$, Jithu Varghese ${ }^{4}$, Heroshy Varghese ${ }^{5}$ \\ ${ }^{1}$ Dept. of Electronics \& Communication Engineering, Baselios Thomas I Catholicose College of Engg \& Tech., \\ Koothattukulam, India \\ ${ }^{2}$ Dept. of Electronics \& Communication Engineering, Baselios Thomas I Catholicose College of Engg \& Tech, \\ Koothattukulam, India \\ ${ }^{3}$ Dept. of Electronics \& Communication Engineering, Baselios Thomas I Catholicose College of Engg \& Tech, \\ Koothattukulam, India \\ ${ }^{4}$ Dept. of Electronics \& Communication Engineering, Baselios Thomas I Catholicose College of Engg \& Tech, \\ Koothattukulam, India \\ ${ }^{5}$ Asst. Prof BTC of Engg \& Tech, Baselios Thomas I Catholicose College of Engg \& Tech, Koothattukulam, India
}

\begin{abstract}
Now a day's every system is automated to face new challenges in present day situations. The automatic systems erase the need for manual operations and thus are reliable, flexible and more accurate. Hence they are used in every field, especially in electronics automated systems. Probably the most useful things to know are about GSM, It is the only type of cellular service available throughout the world. We make use of this GSM capability to develop a system that control and access various units of home appliances, which executes with respect to the signals sent by mobile. A User has an android based cell phone and by making use of a graphical user interface application he is fully able to know the status of his household equipments. The system is intelligent to monitor and control the water level in the tank and also informs the user about any gas leakage in his house.
\end{abstract}

Keywords—Home Automation, Ubiquitous access, Android, GSM, Gas Leakage, Water level control

\section{INTRODUCTION}

In this present day, life has become so fast, so busy and one has no time to feel calm and he always forgets to switch off this household equipment's like fan, lights etc. When he realizes that he forgot to do something, he may be far away from his home. The Project aims to develop an intelligent home automation system that is capable of utilizing mobile technology that keeps control of various household equipment's. Intelligence lies in its ability to monitor and control the water level in the tank and detecting gas leakage in the home. The system is able to inform the user about the equipment status in his android based cell phone. The front end of the project is a graphical user interface application running on android platform. The user is able to know the status of all the household equipments and is able to control it. The water level of the tank can also be manually controlled and its status can be made aware. Whenever a gas leakage is detected the user gets an alert sound in this handheld cell phone. The ease of operation and low cost add up as an additional advantage.

\section{RELATED WORKS}

\subsection{GSM Based Home Automation}

GSM based home automation system makes use of SMS feature of a GSM based cell phone same as the proposed system, but user has to send short text messages to access and control the equipments. There might be many codes for switching the devices to On/Off. It's a bit difficult task for the user to remember all those keywords.

\subsection{Home Automation System (HAS) using Android for Mobile Phone}

Automation System (HAS) has been designed for mobile phones having Android platform to automate an 8 bit Bluetooth interfaced microcontroller which controls a number of home appliances like lights, fans, bulbs and many more using on/off relay. This paper presents the automated approach of controlling the devices in a household that could ease the tasks of using the traditional method of the switch. The most famous and efficient technology for short range wireless communication- Bluetooth is used here to automate the system.

\section{PROPOSED SYSTEM}

\subsection{Introduction}

The proposed system is an intelligent system that has the capability of control over water level in the tank and additional advantage to detecting hazardous situations like gas leakage etc. The user has the track of all the household equipments. 


\subsection{Block Diagram}

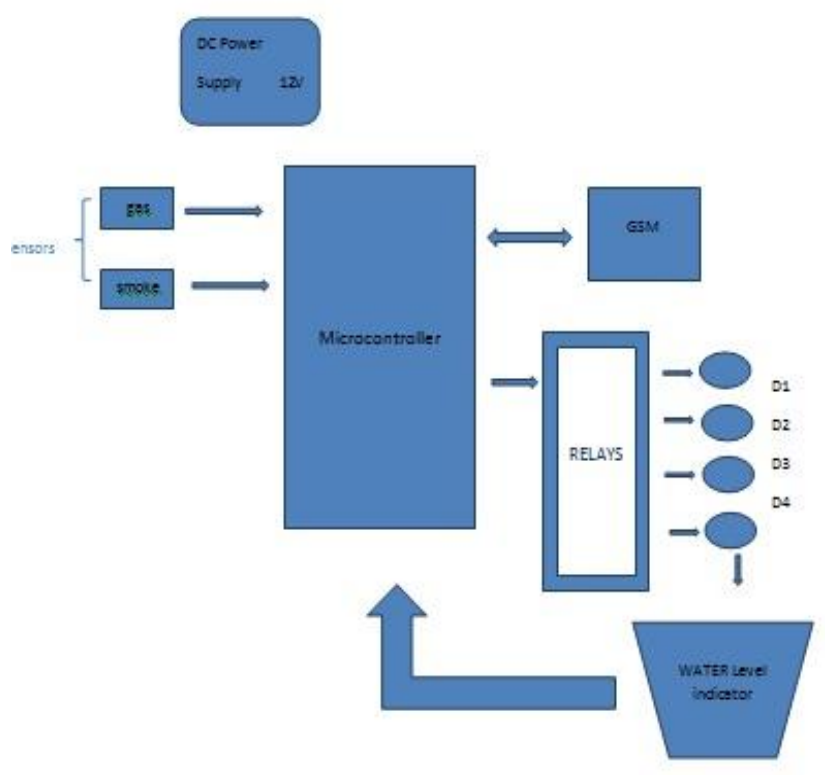

\subsection{Block Diagram Explanation}

The microcontroller (PIC 16F877A) is the processing part of the system. GSM module is connected to it. Whenever the user sends the commands, the GSM module sends it to the microcontroller serially through RS232 interface. The status of the device is sent back to the user via GSM module. The android applications track the keyword and perform the desired operation. The relays to drive the equipments and water level controller and gas sensors are connected to the respective ports of the microcontroller.

\section{ADVANTAGES \& DISADVANTAGES}

\subsection{Advantages}

- $\quad$ Provides ubiquitous access.

- Global range.

- $\quad$ Ease to use.

- Low cost and low power consumption.

\subsection{Disadvantages}

- $\quad$ Delays in mobile networks.

- Need of a dedicated Mobile connection for the system.

- Network provider charges for sending and receiving text messages.

\section{FEATURES OF THE PROPOSED SYSTEM}

The paper presents a novel, standalone system that has full control over the water level of the tank and can detect gas leakage. The user is able to control every equipment in his home, he is able to know its status and switch on/off accordingly. The system is so intelligent that it makes the hand held cellphone to notify the user about the hazard situation such as gas leakage. Also the android based graphical user interface helps the user to understand things better by graphical indication of the status of equipment's, whether it's on or off

\section{GSM TECHNOLOGY}

The system makes use of GSM (Global system for mobile) to accomplish its functionality. User is able to communicate to the hardware from anywhere around the globe since it estimates that $80 \%$ of mobile global market uses this standard. GSM is used by over 3 billion people across 200 countries. User is able to access his home equipment's by using SMS (Short Message Service) facility provided by GSM.

\section{HARDWARE AND SOFTWARE}

\section{DESCRIPTION}

The hardware section consists of PIC18F877A Microcontroller, relays, gas sensor, GSM module

\subsection{GSM Module}

GSM module receives messages from the android based cell phone. It transmits the received data to the microcontroller for switching the devices and sends the device status back to the cell phone.

\subsection{Driver Circuitry}

It consist of relays to drive the household equipment's. The lights and fans are interfaced through LED's that provides the appropriate voltage level for the devices to function.

\subsection{Smoke Sensor}

For smoke sensor the ADC registers are initialized and the voltage is obtained in the analog input pin of the PIC controller

\subsection{PIC16F877A}

It is an 8-bit, 40 pin IC, which is the processing part. Output from different sensors are fed to the ADC of the PIC. It has 368 bytes of data memory, 8 Kbytes of program memory and 256bytes of EEPROM data memory, which are used to store the database.

\subsection{Eclipse}

Eclipse is software designed to create android application. It is based on java programming language.

\subsection{Micro C}

MicroC is a real-time multitasking operating system kernel for microprocessors, it is used to program the PIC and store the database into its dedicated memory. It uses $\mathrm{C}$ programming language.

\subsection{Proteus}

Proteus is a simulation software. It is used to design and test the proposed system. 


\subsection{Boot Loader}

Boot loader is a burning tool. This is used to transfer the code to the PIC microcontroller.

\section{CONCLUSION AND FUTURE SCOPE}

The proposed system is able to coordinate appliances and other devices through short message service. The system can effectively transmit and receive data via SMS. The system eliminates the need of being physically present at any location for task involving the operation of appliances within a household/office.

The scope of the project is immense. The future implications of the project are very great considering the amount of time and resources it saves. The project we have undertaken can be used as a reference or as a base for realizing a scheme to be implemented in other projects of greater level such as weather forecasting, temperature updates, device synchronization, etc. The project itself can be modified to achieve a complete Home Automation system which will then create a platform for the user to interface between himself and the household.

\section{REFERENCES}

[1]. Sweatha K N, Poornima M, Vinutha M H - "ADVANCE HOME AUTOMATION USING FPGA CONTROLLER", International Journal of Advanced Research in Computer and Communication Engineering Vol. 2, Issue 7, July 2013.

[2]. Moshiri B., Khalkhali A. M., Momeni H. R., "Designing a Home Security System Using Sensor Data Fusion with DST and DSmT Methods". Tehran Univ., Tehran; IEEE Publication, (2007)1-6.

[3]. Mahesh N. Jivani "GSM Based Home Automation System Using App-Inventor for Android Mobile Phone" International Journal of Advanced Research in Electrical, Electronics and Instrumentation Engineering Vol. 3, Issue 9, September 2014

[4]. Rosendahl A., Botterweck G., "Univ. of KoblenzLandau, Koblenz "Mobile Home Automation-Merging Mobile Value Added Services and Home Automation Technologies", International Conference on the Management of Mobile Business (ICMB 2007), ISBN: 0- 7695-2803-1, (2007) 31.

[5]. D.NARESH, B.CHAKRADHAR, S.KRISHNAVENI, "Bluetooth Based Home Automation and Security System Using ARM9", International Journal of Engineering Trends and Technology (IJETT) - Volume 4 Issue 9- Sep 2013

[6]. Aniket Yeole, Sapana Bramhankar, Arjun Gaikwad, Abhijeet Bansod, Atul Borade, "RTOS BASED HOME AUTOMATION SYSTEM USING ATMEGA", International Journal of Innovative Research in Computer and Communication Engineering, Vol. 3, Issue 2, February 2015

[7]. R. Hariprakash, G. Venkatramu, S. Ananthi, "University of Madras, K. Padmanahan "Some Problem and Methods for Remotely Controllable Automatic Home Security System" Systems and Networks Communications. ICSNC, 3rd International Conference Publication, ISBN:978-0-76953371-1, (2008) 400-403. 